\title{
Research on Countermeasures for Regional Economic Development of College Business English
}

\author{
Rui Han, Yanlin Yin, Dongmei Li, Qi Liu, Xi Chen
}

Heilongjiang University of Technology, Jixi, Heilongjiang, China, 158100

Keywords: College Business English; economic development; countermeasures

\begin{abstract}
With the progress and development of society, the teaching team of higher education in our country has been growing, and English education in colleges and universities has achieved rapid and innovative development. Many colleges and universities attach great importance to business English education and teaching reform and constantly innovate business English teaching mode. The economic and social development of higher education institutions is a major trend in the development of higher education teaching and an inevitable result of the rapid economic and social development. Based on this, the paper analyzes the problems in the economic and social development of business English service in colleges, and puts forward corresponding countermeasures, hoping to play a role in the development of business English in colleges.
\end{abstract}

\section{Introduction}

At present, China's social economy is developing rapidly, and the diversification of regional economic development has improved the level of education development in colleges, which has brought the relationship between college education and regional economic development closer, and has also brought the university's service society into a new stage. However, considering the actual situation, many colleges in our country do not realize the role of business English talents in promoting regional economic development. Therefore, there is a problem that the cultivated business English talents cannot meet the development requirements of society and enterprises. Under such circumstances, how can we cultivate the business English talents that are welcomed and recognized by society and enterprises? This is a topic that should be explored by major universities and colleges in China. Under the background of global economy and culture, Business English plays a more and more important role. It is of great significance to promote the development of local economy by studying the socialized services of Business English professional and analyzing the social service channels of Business English.

\section{The Importance of Regional Economic Development of College Business English}

With the development of economic globalization, China's major industries have made tremendous changes, especially regional economic development. At present, attaching importance to cooperation with various countries and promoting the sustainable and healthy development of the regional economy have become the first choice for China to improve its overall national strength. In China's economic market, many foreign-funded enterprises have been incorporated, and companies have grown. It is precisely because of this that universities need to develop a steady stream of business English professionals to adapt to the current social development needs of our country. Colleges provide services for the society and participate in market competition. Under the premise of gaining benefits, promoting the rapid and stable development of universities and colleges is the trend of future development. Colleges need to define the objectives of regional talent training in the process of business English majors, and formulate sound personnel training mechanisms, attach importance to research cooperation between industries and universities, rationally conduct education and teaching, clarify the objectives of personnel training in universities, and cultivate professional skills and quality education. A business English talent has laid a solid foundation for 
promoting the further development of the region's economy.

\section{The Impact of College English Education on Regional Economic Development}

First of all, English education in colleges can promote the comprehensive development of economy and technology in our region. Because the speed of global economic integration is accelerating, in order to accelerate the implementation of the strategy of going global in our regional economy, we must meet the challenges of various issues. Language plays an important role in market possession and development, technological innovation and management. Language can not only reflect the cultural differences in economic and trade, but also reflect the specific differences of knowledge meaning, the differences in technical meaning, the differences between management and so on. To break through the intangible barriers and shackles of our global economic integration, we must pay attention to English education. Our college English education can continue to provide professional English education for various professionals, such as medical English, engineering management English, customs English and other professional English education, which can promote the rapid development of our regional economy and help us to shop faster. Into the wave of the world's integrated economy.

Secondly, English education in colleges can promote the development of regional foreign trade economy. The economy of a country or region can be divided into two parts, the domestic and foreign economies. The classification of English education in our colleges is clearer and more detailed than that of middle school English. It can provide the market with all kinds of relevant English talents, promote the exchange of foreign exchanges in our region, and promote the diversified and long-term development of regional markets. Foreign investment and learning of advanced management and engineering technologies have played an active role in reducing trade frictions and disputes.

Third, our English education in colleges can also promote cultural prosperity in our local region. Our English education in colleges can strengthen our foreign language education in Shangqiu. Enhance the economic and trade development of our Shangqiu region and expand the introduction of foreign investment. Through the systematic management and study of foreign languages in Shangqiu, we can deeply understand the background of English culture and gain an in-depth understanding of international business rules and trade norms.

\section{Strategies for the Regional Economic Development of College Business English}

Focus on close cooperation with regional governments and strive to improve various systems. In promoting economic development, regional economic development has the characteristics of instability. The speed of enterprise development is also in the process of improvement. The government should increase its efforts to grasp the development trend of business English majors, provide policy guarantees, and effectively improve the ability of personnel training. In the actual development process, government departments should in-depth study of professional development, in-depth discussion of regional development issues, and develop appropriate solutions to the problem-solving measures to ensure that business English professional can be closely linked with the company to achieve healthy and stable development of the enterprise The actual demand will effectively implement the policies for the local colleges to serve local talents and cultivate more high-quality business English professionals for the society and enterprises. At the same time, in all aspects, the vigorous development of higher education will benefit both the government, the enterprises, and the universities. It is also an investment that can be felt and seen. Therefore, colleges should plan the construction of practical training bases to ensure sufficient financial resources. After finding cooperative enterprises, they can ensure that enterprises can actively and effectively cooperate with universities, and strive to cultivate a steady stream of business English professionals for society and the country. .

To promote the development of regional economy and determine the direction of personnel training. In promoting regional economic development, the business English major provides a lot of 
services. The most important thing is to cultivate foreign trade talents with high quality. The professional characteristics of business English should focus on improving the quality of regional economic talents. It is necessary to do a good job in market research in setting up professions and training channels to promote regional economic development, so as to meet the demand for professional talents required by foreign trade enterprises. Under this circumstance, we should reform the talent cultivation structure and form a talent training model that is consistent with the requirements of regional economic development, so as to effectively cultivate the applied talents needed by society and enterprises.

Play the professional characteristics of business English and actively build local culture. In the context of the increasing popularity of education, the cultural communication of higher education institutions must not only meet the cultural needs of teachers and students, but also be closely related to the construction of social culture, attracting more members of the public to participate in education. In the construction of regional economy and culture, college business English majors should work in concert with local cultural departments to achieve effective integration of campus and campus culture and strengthen each other, and work together to create a sound and harmonious regional economic culture.

Pay attention to the cooperation with enterprises and ensure the diversity of training methods. The establishment of business English majors in colleges has a lot to do with the healthy development of the regional economy. In the process of cultivating business English talents, we should pay attention to cooperation with major companies and provide specialized training for current professional and technical staff so that professionals can give full play to their professional advantages. In addition, we must also focus on cooperation with foreign companies, do a good job in translation services, increase the intensity of training professionals in education, and increase the awareness and ability of professionals in innovation so that professional talents can be recognized and appreciated by business leaders. Today, in the information age, whether it is between various countries or between major companies, the competition is fundamentally the competition of talents. Therefore, enterprises and colleges should provide a variety of training methods for business English professionals, and create favorable conditions for achieving a win-win situation.

In recent years, the work of English education in colleges in China has continued to deepen and has achieved remarkable results. However, with the development of the regional economy, this "teaching + production" model needs to be further enhanced. To this end, it is necessary to strengthen the ability of college English education to serve the regional economy by relying on the reinforcement of teacher resources, and establish a balance based on scientific research, institutions, and students through cooperation between higher education fields and related institutions in the region. For example, through training and talent introduction, teachers who are teaching English in colleges can not only have a good academic background, but also be proficient in languages other than English (especially in small language). Through the optimization of mechanism or physique, English teachers in universities can have the opportunity to participate in more academic conferences and conduct comprehensive exchanges and discussions in the professional field. In the region, organize and participate in a variety of academic activities, enhance the exchanges and exchanges between university teachers, and make the English teaching of higher schools more obvious professional and skilled.

In order to strengthen the coupling mechanism between college English education and regional economy, college English curriculum should reflect the characteristics of diversification and individualization, so as to maintain coordination with the market economy. In accordance with the regional and regional economic development level, colleges should position the school level and personnel training, and provide targeted English courses based on the analysis of the industrial development in the region. In addition, in order to maximize the role of college English education, the instructor should provide students with a wide range of English elective courses in accordance with their professional direction and interest orientation. In terms of the coupling of college English education with regional economies, Russia, the United States, the United Kingdom, Japan, and South Korea all have advanced experiences that are worth learning from. Through the study of the 
experience of developed countries, the positioning of English teaching in colleges has always been at a global level. The establishment of this educational orientation requires the entire society to provide a good external environment for college English education. Only in this way can a university student who has gone on a career path pass the examination of occupational positions within the region, so as to contribute more to the development of the regional economy.

\section{Conclusion}

Training business English professionals in colleges is the need to promote regional economic development, is the purpose of running colleges, and is also a major function of higher education institutions. In the current society, no matter which professional development, it is necessary to closely link with the regional economy, turn the teaching goal into promoting regional economic development services, effectively help local governments deal with the problems in the process of economic development, and promote the further development of the local economy. The goal of cultivating business English professionals has put forward many requirements for college teachers. It requires college teachers to change traditional teaching concepts and methods in a timely manner, adopting a variety of new teaching methods to improve students' professional ability, so that students can work smoothly and promote regional economy. Development contributes to one's own strength.

\section{Acknowledgements}

Fund Project: 2017 Jixi Social Science Research Project (key projects);

Project Name: Research on the Countermeasures of Regional Economic Development of College English Service_- Taking Jixi as an Example

Project Number: 2017JSK063

\section{References}

[1] Shi Yan. College English Education and Regional Economic Development in the Perspective of Language Economics [J]. Chinese Language and Literature, 2015(1): 56 - 58.

[2] He Fan. Cultivation of Business English Talents from the Perspective of Regional Economy [J]. Examination Weekly, 2014, (64): 72.

[3] Wei Fang. Training of Higher Vocational Business English Talents Serving Regional Economy [J]. Journal of Wuhan Metallurgical Management Cadre College, 2014, (3): 84-86.

[4] Wang Shaohao, Lin Wei. Promotion of regional economic development and cultural dissemination through practical teaching of business English: based on empirical analysis of Lin Ma Village aid construction [J]. Journal of Heilongjiang College of Ecological Engineering Vocational Education, 2017, (3):115-117.

[5] Xu Y. Research on the Countermeasures of Business English Service Regional Economic Development [J]. Journal of Hunan Taxation College, 2017, (4):52-55. 